\title{
Ripening and Postharvest Storage of Pawpaw
}

\author{
Douglas D. Archbold, ${ }^{1}$ Rumphan Koslanund, ${ }^{2}$ and Kirk W. Pomper ${ }^{3}$
}

Additional Index words. kentucky banana, Asimina triloba

Summary. To facilitate the growth of a commercial pawpaw (Asimina triloba) industry, several problems with harvest and postharvest handling of fruit need to be resolved. Pawpaw fruit ripening is characterized by an increase in soluble solids content, flesh softening, increased volatile production, and a loss of green color intensity. Within 3 days after harvest, ethylene and respiratory climacteric peaks are clearly evident. Softening of fruit is due to the action of at least four enzymes, with the softening proceeding from the surface to the interior tissue. Fruit on a single tree can ripen over a 2 -week period, creating labor problems. When immature fruit is harvested it does not ripen, even if treated with ethephon at $1000 \mathrm{mg} \cdot \mathrm{L}^{-1}$ $(\mathrm{ppm})$, but the use of commercially available growth regulators both pre- and postharvest warrants further study. Fruit soften very rapidly at room temperature after harvest and have a 2 -to 4 -day shelf life. However, we have stored pawpaw fruit for 1 month at $4{ }^{\circ} \mathrm{C}\left(39.2{ }^{\circ} \mathrm{F}\right)$ with little change in fruit firmness and fruit apparently continue normal ripening upon removal to ambient temperature. The optimum temperature and duration for holding fruit will need to be determined. Further extension in pawpaw storage life may be feasible with controlled or modified atmosphere storage. Although there are a number of practical problems with pawpaw harvest and postharvest storage that need to be addressed, we hope to develop recommendations for harvest and handling of fruit in the near future.

The pawpaw fruit has become the focus of a significant regional effort to expand its production and marketing. The unique fruit qualities of pawpaw suggest that it has great potential as an alternative highvalue crop in the eastern United States and beyond. The primary impediment to introduction of pawpaw into both fresh and processing markets is its perishability (Peterson, 1991), first noted in 1916 by the American Genetics Association (Popenoe, 1916, 1917). To date, appropriate harvest and storage practices for pawpaw fruit have not been studied. In order to facilitate the growth of a commercial pawpaw industry, we are evaluating harvest indices and storage techniques with the goal of developing a set of recommendations for handling the fruit. The primary problems, though not mutually exclusive, can be broadly categorized as ripening issues and cold storage issues.

\section{Ripening}

Pawpaw fruit ripening is characterized by an increase in soluble solids content (up to $20 \%$ ), flesh softening, increased volatile production, and, in some genotypes, a decline in green color intensity (McGrath and Karahadian, 1994). The volatile profile during ripening consists primarily of ethyl and methyl esters (McGrath and Karahadian, 1994; Shiota, 1991).

${ }^{1}$ Professor of horticulture, Department of Horticulture, University of Kentucky, Lexington, KY 40546-0091. To whom reprint requests should be addressed.

${ }^{2}$ Graduate student, Department of Horticulture, University of Kentucky, Lexington, KY 40546-0091.

${ }^{3}$ Principal investigator of horticulture and curator, USDA National Clonal Germplasm Repository for Asimina species. Atwood Research Facility, Kentucky State University, Frankfort, KY 40601-2355. 
Although it has been reported that pawpaw fruit are climacteric, exhibiting an increase in respiration and ethylene production during ripening, the evidence is anecdotal (Peterson, 1991). We found that within $3 \mathrm{~d}$ after harvest, ethylene and respiratory climacteric peaks were clearly evident as the fruit were rapidly softening (Fig. 1) (Koslanund, 2003). Pawpaw is a member of the Annonaceae family along with tropical fruit like cherimoya (Annona cherimola), sweetsop or sugar apple (A. squamosa), soursop (A. muricata), and atemoya ( $A$. squamosa $\times A$. cherimola), all of which are climacteric (Biale and Barcus, 1970; Brown et al., 1988; Kosiyachinda and Young, 1975; Paull, 1982; Wills et al., 1984). Fruit of these species exhibit similar climacteric maxima, although some have two respiratory peaks which we have not observed with pawpaw. Our preliminary analyses indicate that the decline in firmness is due to the action of at least four enzymes, polygalacturonase, cellulase, pectin methylesterase, and endo- $\beta$-mannanase (Koslanund, 2003). Softening of the fruit appears to proceed from the surface to the interior tissue during the ripening process. Polygalacturonase and cellulase have been related to the decline in cherimoya firmness (Sanchez et al., 1998). The precise roles of each enzyme and whether or not ethylene regulates their activities needs to be determined in pawpaw.

Pawpaw fruit have traditionally been harvested from native plant stands and small orchards for immediate sale and/or consumption. Other than the decline in fruit firmness, there are no obvious indicators of fruit ripening. This lack of a good harvest index is also a problem with the related cherimoya (Merodio and De la Plaza, 1997). A decline in green color intensity during pawpaw ripening was reported (McGrath and Karahadian, 1994), but we have found that it is not consistent among genotypes, occurs later in ripening if at all, and is not easy to visually identify. A common practice is to touch each fruit to determine if it is ready to harvest. Thus fruit are harvested when they have already begun ripening and have lost some firmness. This is labor intensive and may result in slight bruising injury, perhaps leading to off-flavors (Peterson, 1991). To maximize the length of time fruit can be stored, it would be best to harvest fruit at the earliest stage of ripening. The means to determine this stage needs to be developed, and the impact of off-tree ripening on fruit quality needs to be assessed.

The fruit on a single tree do not ripen within close proximity in time to one another. An extended harvest period of 2 weeks or so from a tree is not uncommon. The protracted harvest may be due in part to the staggered bloom period in the spring, up to 2 weeks or so, but it is not known if the bloom to harvest period is the same for all fruit on a tree. In fact, each fruit cluster develops from an individual flower, and fruit within a cluster often ripen at different times. Cultivar variation in harvest date also exists with early to late season cultivars ripening over 4 to 6 weeks. Currently, multiple harvests from one tree are conducted to obtain high quality fruit. Because a decline in firmness is the main indicator of ripening, this requires repeated visits to, and touching of, individual fruit which is a very laborious task. A once-over harvest from a tree currently is not feasible.

Preharvest application of growth regulators may be useful tools for manipulating the initiation of pawpaw fruit ripening and concentrating the harvest period, necessitating fewer harvest dates per tree. Such manipulation of ripening is feasible in fruit species in which ripening is ethylene-regulated
(Miller, 1989). Examples include the use of ethephon for ethylene release to get more uniform ripening and abscission, and the ethylene action inhibitor aminoethoxyvinylglycine (AVG) for delaying ripening and harvest. Treatment of the related sweetsop with AVG reduced ethylene evolution and delayed ripening (Tsay and $\mathrm{Wu}, 1989$ ). Since pawpaw exhibits an ethylene climacteric, it too may be susceptible to ethylene treatment to induce ripening and/or treatments to affect ethylene production or action. We found that fruit harvested immature did not ripen, even if treated with ethephon at 1000 $\mathrm{mg} \cdot \mathrm{L}^{-1}$, but the use of commerciallyavailable growth regulators to manipulate pawpaw ripening warrants further study. Postharvest application of 1-methylcyclopropene, an ethylene action inhibitor, has recently been used to successfully slow the ripening of climacteric species and may be useful for doing the same with pawpaw (Fan et al., 1999; Golding et al., 1998).

\section{Postharvest handling}

Pawpaw fruit are green and some genotypes lighten some with ripening. Unfortunately, fruit can often exhibit some surface browning. Lacking easily identifiable ripening traits as noted above, it remains to be determined how to sort harvested fruit other than by hand. This could be done by touch at harvest with the softer fruit going for

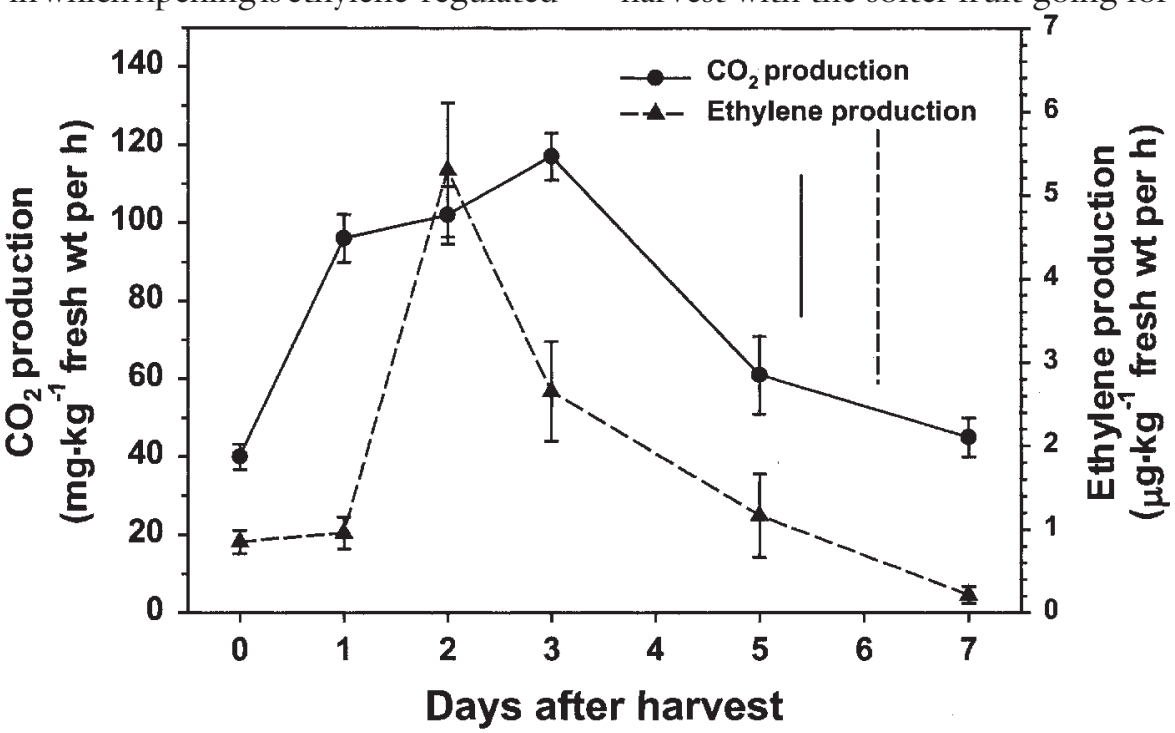

Fig. 1. Respiration rate [carbon dioxide $\left(\mathrm{CO}_{2}\right)$ production] and ethylene production of pawpaw fruit. Fruit were ripening at harvest, as some softening was evident to touch. Data are from the 1998 and 1999 harvests of more than 20 genotypes at the Kentucky State University Research Farm, Frankfort, Ky. Techniques for measuring the gases are described in Koslanund (2003). The means and standard errors are from $\mathbf{4 0}$ fruit. The separate vertical bars are the least significant difference at $P=0.05$. 
immediate transport to market and the firmer fruit headed to storage. Systems that sort by color such as with apple (Malus $\times$ sylvestris var. domestica) (Tao et al., 1995) might be useful if fruit color can be accurately determined, as green color intensity declines as fruit ripen in some genotypes (McGrath and Karahadian, 1994). However, green color intensity must first be closely correlated to ripening stage across cultivars.

Pawpaw fruit soften rapidly at room temperature after harvest. McGrath and Karahadian (1994) and Layne (1996) indicated a 2 -to-3-d shelf life was to be expected, although we have observed that those fruit at the earliest stage of ripening may have a 5-to-7-d shelf life. Refrigeration is a likely solution for slowing the loss of firmness and short-term storage. Cherimoya suffer chilling injury at temperatures below $7{ }^{\circ} \mathrm{C}\left(44.6^{\circ} \mathrm{F}\right)$ (Alique et al., 1994). However, we have observed that pawpaw fruit can be stored for 1 month at $4{ }^{\circ} \mathrm{C}$ with little change in fruit firmness and apparently continue normal ripening upon removal to ambient temperature. We say apparently because not all ripening traits were evaluated, nor were post-storage taste tests performed. The optimum temperature and duration for holding the fruit will need to be determined. A 4- to 8 -week coldstorage period after harvest could help with an orderly marketing schedule. Combined with a range of harvest periods from different cultivars, the season could be extended from the current 4 to 6 weeks now to 8 to 12 weeks. Further extension in pawpaw storage life may be feasible with controlled or modified atmosphere storage (Thompson, 1996).

Regardless of the method and details of storage, the quality of fruit ripened after cold storage must be consistent with that which occurs without storage. This is true not only for the continuing decline in firmness but the development of flavor and soluble solids content as well. The flavor of pawpaw fruit is very distinctive and needs to be preserved for the consumer.

\section{Conclusion}

There are a number of practical problems with pawpaw harvest and postharvest storage. A greater understanding of pawpaw ripening physiology and the role of ethylene in coordinating the process is needed. The solutions to the current problems may mean applying common harvest and storage techniques from other tree fruit crops to pawpaw. Many techniques need to be assessed to identify those most applicable to extending pawpaw storage life while maintaining high fruit quality. We are currently studying these problems and assessing potential solutions. With good fortune there may be recommendations for pawpaw harvest and handling in the near future.

\section{Literature cited}

Alique, R., J.P. Zamorano, M.L. Calvo, C. Merodio, and J.L. De la Plaza. 1994 Tolerance of cherimoya (Annona cherimola Mill.) to cold storage. J. Amer. Soc. Hort. Sci. 119:524-528.

Biale, J.B. and D.E. Barcus. 1970. Respiration patterns in tropical fruits of the Amazon basin. Trop. Sci. 12:93-104.

Brown, B.I., L.S. Wong, A.P. George, and R.J. Nissen. 1988. Comparative studies on the postharvest physiology of fruit from different species of Annona (custard apple). J. Hort. Sci. 63:521-528.

Fan, X., Blankenship, S.M., and J.P. Matthews. 1999. 1-Methylcyclopropene inhibits apple ripening. J. Amer. Soc. Hort. Sci. 124:690-695

Golding, J.B., Shearer, D., Wyllie, S.G., and W.B. McGlasson. 1998. Application of l-MCP and propylene to identify ethylenedependent ripening processes in mature banana fruit. Postharvest Biol. Technol. 14:87-98.

Kosiyachinda, S. and R.E. Young. 1975. Ethylene production in relation to the initiation of respiratory climacteric in fruit. Plant Cell Physiol. 16:595-602.

Koslanund, R. 2003. Ethylene production, fruit softening, and their manipulation during pawpaw ripening. $\mathrm{PhD}$ diss. Univ. Ky., Lexington.
Layne, D.R. 1996. The pawpaw [Asimina triloba (L.) Dunal.]: A new fruit crop for Kentucky and the United States. HortScience 31:777-784.

McGrath, M.J. and C. Karahadian. 1994. Evaluation of physical, chemical, and sensory properties of pawpaw fruit (Asimina triloba) as indicators of ripeness. J. Agr. Food Chem. 42:968-974.

Merodio, C. and J.L. De la Plaza. 1997. Cherimoya, p. 269-293. In: S. Mitra (ed.). Postharvest physiology and storage of tropical and subtropical fruits. $\mathrm{CAB}$ Intl., New York.

Miller, S.S. 1989. Plant bioregulators in apple and pear culture. Hort. Rev. 10 309-401.

Paull, R.E. 1982. Postharvest variation in composition of soursop (Annona muricata L.) fruit in relation to respiration and ethylene production. J. Amer. Soc. Hort. Sci 107:582-585.

Peterson, R.N. 1991. Pawpaw (Asimina). Acta Hort. 290:567-600.

Popenoe, W. (ed.). 1916. Where are the best papaws? J. Hered. 7:291-296.

Popenoe, W. (ed.). 1917. The best papaws. J. Hered. 8:21-33.

Sanchez, J.A., J.P. Zamorano, and R. Alique. 1998. Polygalacturonase, cellulase and invertase activities during cherimoya fruit ripening. J. Hort. Sci. 73:87-92.

Shiota, H. 1991. Volatile components of pawpaw fruit (Asimina triloba Dunal.). J. Agr. Food Chem. 39:1631-1635.

Thompson, A.K. 1996. Postharvest technology of fruits and vegetables. Blackwell Science, Oxford, England.

Tao, Y., P.H. Heinemann, Z. Varghese, C.T. Morrow, and H.J. Sommer, III 1995. Machine vision for color inspection of potatoes and apples. Trans. Amer. Soc. Agr. Eng. 38:1555-1561.

Tsay, L.M. and M.C. Wu. 1989. Studies on the postharvest physiology of sugar apple. Acta Hort. 258:287-294.

Wills, R.B.H., A. Poi, H. Greenfield, and C.J. Rigney. 1984. Postharvest changes in fruit composition of Annona atemoya during ripening and effects of storage temperature and ripening. HortScience 19:96-97. 